\title{
The Necessity of Using Foreign Capital in the Croatian Economy
}

\author{
Dr. Sc. Ana Vizjak \\ Associate Professor, Faculty of Tourism and Hospitality Management, Opatija \\ anav@fthm.hr \\ Maja Vizjak, Mag. Oec \\ Faculty of Tourism and Hospitality Management, Opatija \\ vizjakmaja1@gmail.com
}

\section{Doi:10.5901/mjss.2015.v6n2s5p55}

\begin{abstract}
Croatia, like most developing countries, is facing a shortage of capital for its economic development. Acceptance of foreign capital in the national economy should be regulated by legislative and economic regulations that would allow its unobstructed acceptance. In this process, it should be taken into account that investments should be pointed in the most favourable direction in order to encourage social development, but also ensure profit to potential investors. Foreign capital in the Croatian economy can operate in several directions: as international public capital, capital of international institutions, state capital, private capital, while in practice, there are also other forms of capital. In the present social moment, in terms of economic and legal insecurity in the country and high level of corruption, serious foreign public and private capital primarily shows interest in investing in major infrastructure facilities such as roads, ports, tourist facilities, and other facilities, and seeks to provide direct protection of the state. Croatian businessmen at lower levels of development as well as various entrepreneurs who would like to incorporate foreign capital in their business activities should make sure to use this capital in the realisation of the planned social development, and avoid foreign venture capital in the process. They should primarily demand legislation from the state that would provide them with legal and financial security of their investments. Investment experts recommend services of internationally acclaimed and reputable businesses that should be used to make investments in the country.
\end{abstract}

Keywords: foreign capital, investment, economy, development

\section{Introduction}

The economic system of the Republic of Croatia operates in the environment of Central European transition countries that orient their economic development towards the open and free social market economic system of the Western type. Within this system works an adequate system of property relations, entrepreneurial management, economic and political democracy, the rule of law and a certain level of social protection and human rights. Presently, Croatia is an European Member State, and it also needs to be fairly and effectively involved in European and global economic trends. Successful achievement of the above-mentioned requirement and the necessity to encourage such transformation processes would regulate internal relations in all segments and activities in the Croatian society, with special attention devoted to property, market, entrepreneurial management, organisation and management of business and other entities. In order to achieve such great economic and political changes in the country, it is necessary to acquire the appropriate modern knowledge, abilities, and skills, develop entrepreneurial spirit, innovativeness, all of which is included in human capital development, and particularly bring into the country new, fresh financial capital. At the time of property transformation and privatisation, there was a slightly better situation with large infrastructural government systems, where large-scale foreign investors appeared as buyers or investors, investing their capital into certain facilities or attempting to gain the majority of shares in all the systems such as banks, highways, insurance, etc. Of all the investments, 57,9 per cent occur in the private sector, and 26,6 per cent in the government sector.

The main hypothesis: Further development of the Croatian economy should be based on the belief that, along with all the forms of domestic capital, foreign capital is also necessary for future development of the country. PH1: Croatian economic development, according to all the relevant plans and indicators, is based on such viewpoints, and future strategic objectives are necessarily linked with an increase in material well-being of Croatian citizens, their material and spiritual wealth and quality of life. PH2: The realisation of these objectives should depend on successful management of 
natural, technical, and human resources, i.e. economic and social efficiency of national economic operators, all of which affects the development of the national economy as a whole. The objective of this paper is to point to the necessity for a high level of transformation in the field of engineering, technology, organisation, management methods, but also the entire economic structure and structure of employees, with special attention devoted to entrepreneurial and managerial staff. All of this can be very effectively achieved by using foreign knowledge, techniques, technology, and capital. The scientific contribution is reflected in the development of scientific thought about the importance of changes in the social and economic environment of the country, but without the creative acceptance of useful global achievements from developed countries, one cannot be equally and effectively engaged in global economic trends or European economic and political integrations. Membership in the European integrations can significantly contribute to development of Croatian economy, but only to the level at which we are trained to use these achievements. Scientific methods used in this paper are methods of systematic analysis, dialectical and logical method, mostly in the combination inductivedeductive and vice versa, deductive-inductive. Quantitative and qualitative methods were used with methods of comparison of spatial and temporal characteristics.

\section{Social Development and Foreign Investments}

Along with evident development processes and economic transformation and restructuring of the country, it was soon noted that further development of the Croatian economy would not be able to continue without extra capital. Since extra capital from domestic sources is presently insufficient, it is necessary to enable free access of foreign capital to the country. In order to do this without causing major economic shocks, legislation should be used to achieve economic relations in the country that would enable majority control of domestic population over the capital. This is especially important in the segment of land ownership where a small country of this size can, part by part, be bought by any large multinational company. Its population can be moved out under different excuses and national demography can thus be changed. Unfortunately, domestic population in these areas has very bad experiences with foreign investors and investments of this type. Current experiences of other transition, underdeveloped or colonial countries indicate that foreign capital primarily aims to gain its own profit regardless of future consequences for the country they invest in. In this regard, owners of foreign capital in the recipient country should be controlled by legislation, and any kind of illegal behaviour should be prevented. In this way, their capital interest would be in line with domestic interests in the long run.

When foreign capital enters Croatia, one should bear in mind to ensure that economic ratio with domestic source of capital remains undisturbed, and attention should especially be devoted to quality distribution of social costs and tax obligations. The use of contemporary technical and technological solutions should be encouraged, as well marketing, and effective appearance at the global market. Foreign investments should be used in joint investments based on a welldesigned national developmental economic policy. When foreign capital is invested in economic facilities, national investment should be estimated realistically. Price and location of the land are very important. Land ownership as an investment should, as a rule, stay in domestic ownership. This particularly refers to top quality agricultural continental land, while coastal, riverbank, and seashore land should not be sold, but rather rented for a short or long period of time. In this process, the use of the land and economic facilities should be conditioned by application of the most contemporary technological know-how, including the obligation to implement environmental protection (Aćimović, 1987). This could be achieved by using an adequate system of mortgage loans that would be applied in the economic activities. In this process, Croatian owners of capital who work and reside abroad should also be included in the system.

State capital, that needs to be legally defined, plays a very important role in Croatia. In the earlier economic system, state capital had operated in all segments of economic life in the country, while investments were exclusively under government control. Nowadays, in the age of neo-liberalism, the market system forces the creators of economic policy in the country to turn public companies into private enterprises, while the state should create a legal framework for such a transformation.

According to recent experiences in the majority of transition Member States, the government will remain the leading investor for a long time, as well as manager in some infrastructural industries of importance for the state. However, this should not be tolerated for too long, and conditions should be created for approaching private capital that must operate under government control, because it cannot be allowed that citizens are encroached due to various misunderstandings among owners of the capital. Refinancing is an important developmental factor in the economic system of any country. The refinancing system in Croatian economic systems, in the manner in which they have been used until now, should undergo significant changes. The effects achieved in the economic field in Croatia by refinancing point to the fact that refinancing has not been efficiently used in the sense of using extra capital, whether domestic or foreign, which would be used for national technical, technological, organisational or managerial adjustment of the existing 
economic system. The original idea was to use for this purpose the capital obtained by selling the shares in the process of sub-shareholding of former social companies. The gained capital soon disappeared in various embezzlements of leading governmental structures.

All things considered, there is no great quantity of free capital in Croatia that could be used to enter larger economic transformations and investments. Also, foreign debts are substantial and there is no real opportunity for increasing government debts, without causing a large-scale economic crisis.

For making investments in the national economy, one should realistically consider the capital of Croatian citizens working abroad. According to statements of the financial bodies of the countries in which Croatian citizens are living and working, this capital is quite large and it is estimated to tens of billions of dollars.

When we analyse the latest experiences with the redemption of shares of certain large companies, except those that had a monopoly at the market and were protected by the state, they were not particularly stimulating. After they had bought the shares of such companies, they went bankrupt, and shareholders lost their invested funds. The current situation on the capital market, as well as new trends, indicate that foreign and domestic owners of capital would be more inclined to buy certain smaller enterprises and take full control over their business activities, than invest into shares, with which persons who are sometimes connected with organised crime would trade at the market.

An important role in Croatian economic development should belong to owners of small capital, primarily Croatian citizens who gained their capital abroad, and who could invest their capital in small and medium-sized enterprises. These enterprises could become a new foundation on which one could revive weary economic flows that were oriented for years towards government bodies and had political influence on them.

All things considered, foreign and domestic investments should be directed to follow the trend of total economic development along with efficient government protection, but also assistance of financial institutions that should provide capital investors with certain benefits and guarantees that are common in the countries of developed market economies. These would be: tax and customs benefits, reduction of taxes and employee contributions, solving of insolvency, limitation of legal proceedings duration, reduction of administration, possibility of fast transfer of profit, use of different types of mortgages, etc. Most importantly, legal and economic factors should be created that would provide equal chances to everyone in the economic competition. In this process, competitive relations should be created in which the realised profit would not lag behind other, neighbouring competitive countries (Vizjak 1995, 227).

\section{Adjustment of the National Market to Foreign Investments}

For correct, effective, and safe investment of capital, the national market should be well-organised, and one should think about the effects of the investment on certain segments of the society. A point of consideration is also operation of some important market factors, because their timely synchronisation is important for improved access of domestic and foreign capital to the country's economic structure. Successful economic market activities of Western type depend on successful overcoming of various legal or economic barriers at the national market. When adjustment in the market area is taken into consideration, in order to accept domestic or foreign investments, the idea is to establish and develop a complex national market with all its constituent parts. This is not only the market of goods and services; this system should, except labour and services, also include capital and knowledge, as well as all their sub-systems. In this way, a market would be created that would be open to the maximum, and operating enterprises could at all times obtain all the necessary factors, production and business inputs, and use entire, but fair competition, and place their products and services - outputs into any other country at the foreign market (Ostojić 1996, 67.). In order to achieve comprehensive adjustment processes in the national market, and to enable successful acceptance of capital investments, there are many limitations in practice resulting from the application of certain adjustment operations, when underdeveloped marketing culture or wrong economic moves become visible, by those in charge of designing applicable operating systems. According to data by the Financial Agency, 733 industrial enterprises in foreign ownership pay average net wage of KN 5477, while the average wage in 10,826 domestic industrial enterprises is, on average, lesser by as much as KN 1066, which means that a foreigner is a more desirable employer. Out of 48 state companies, 36 gained profit, while 12 suffered loss in the amount of KN 1064 billion. The greatest winners are HEP, HKZP, Plinacro, ARZ, Hrvatske šume, and the greates losers are HPB, Petrokemija, Croatia osiguranje, HŽ Cargo, Đuro Đaković. From January until September of 2014, there was a total of KN 6338 billion of investments, which is 16,1 or one sixth less than in the same period 2014. As much as 47 per cent of investments in state companies were in the following three: HEP, in the amount of KN 1,15 billion, INA with KN 1,08 billion and Hrvatske vode with KN 751,9 billion (Jutarnji list, January of 2015). Some entities in charge of designing economic strategies often present market systems from the period when capital development was at a lower level, or its liberal, a bit more developed stage, which causes resistance and fear of the users of the system. At the same time, quite 
a few businessmen learnt some important different and more humane characteristics of the modern, developed Western market through their co-operation with foreign countries. Many of the so-called experts think that foreign experiences can easily be integrated into the Croatian economic system, using government's force. This is why users of the national economic system are facing unnecessary dilemmas. Therefore, one should get well-acquainted with foreign economic conditions and practice, and think about which one of them would have the best effect in Croatian practice in the given time and space.

\section{Foreign Capital as Stimulation to Development of the Croatian Economy}

Given that Croatia was one of the most developed republics in the former state, that reached a high level of economic cooperation with foreign countries, needs for new capital investments from abroad were treated as a normal economic occurrence. When Croatia became independent, the necessary legislation was adopted at expedited proceedings which specified the conditions of entrance of foreign capital to Croatia. Owners of foreign capital became equal with domestic owners. In this process, the rule "everything that is not specifically forbidden is allowed" was applied. However, the established legislation was not accompanied by other conditions that would in practice regulate the inflow and the manner of operation of foreign capital in the country. It soon became evident that the legislation was superficial and incomplete; various "businessmen" from abroad or from Croatia, in agreement with the highest state officials without capital of their own, bought everything of any value in the country.

Some time later, Croatia started opening itself towards Europe and the rest of the world, and foreign capital of a more "decent" kind started showing interest in making investments in the country. Soon, the first results started showing at the international market with strong attempts to make up the lost time. This is when attention started to be devoted to the need to define foreign capital according to possible forms and sources, its allocation, way of co-operation, and all other factors in order to stimulate faster development of the Croatian economy. There is an estimate of the European Commission that this year in Croatia, there will be good business opportunities, because in the next 3 years economy will be stimulated by investments higher than EUR 300 million, which will result in opening of 1,3 million of new workplaces in the framework of the great Juncker's Recovery Plan (Jutarnji list 23.2.2015). In the scope of the Juncker's plan, Croatia proposed 68 projects in the value of EUR 19,3 billion, from which 24 were adopted in the value of EUR 9 billion as the ones that should be realised with the help of private initiatives. So far, Croatia has signed contracts for projects worth EUR 900 million from the offered EUR 1,2 billion from the EU funds, while EUR 500 million have been realised. Until February 2015, the announced signed contracts are worth KN 5 billion, and until the end of the year, more then KN 10 billion (Jutarnji list 02.12.2014). The most significant projects are LNG terminal in Omišalj (supported by both EU and Washington), the Adriatic-Ionian pipeline, portable power system, the E-schools project, ICT and broadband projects, hydropower plant Kosinj, thermo power plant Plomin C, Zagreb upon Sava (EC, Croatian government). The list also includes investments related to road, rail and air traffic, state-owned companies in the water industry, and HEP (Novi list 01.12.2014.).

\section{Foreign Investments in the Croatian Economy}

Modern Croatian economy accepts all of the above-mentioned forms and sources of foreign capital. In the long run, the most favourable would be loan capital, i.e. interest-based or investment, i.e. profit-making capital. Strong development of the securities market in Croatia leads to a greater inflow of portfolio capital.

Special attention should be devoted to the human capital necessary for social development of Croatia. Great social and economic processes, changes and transitions are not a coincidence, but a result of interactive development of nature, and human scientific activities (Pulić and Sundać 2001,5). Croatia has many educated employees and staff members, which is a large development potential; however, their knowledge and skills are partly outdated, especially from the aspect of contemporary needs and demands of market economy. Sometimes, there is also a need to import entreprenurial-managerial human capital that should increase the level of domestic education in co-operation with the domestic capital. Society members who are not highly educated, but rich in honesty, good will, kindness and integrity, could also contribute to the creation of a society of well-being. (Zelenika 2007, 195). We need as many distinguished, talented and hard-working students in faculties as possible, and direct the already employed to life-long learning and training courses abroad. This especially relates to scientists and top managers.

From 1993 to 2006, about EUR 13,2 billion was invested in various parts of the Croatian eonomic system, and the majority of foreign capital preferred the financial part of the economy, in which about EUR 3,3 billion was invested (Buletin of the Croatian National Bank, 2006). From 1993 to 2000, about USD 4,5 billion of foreign investments were made in 
Croatia. In this mass of investments, of about USD 3,6 billion, about 80 per cent or USD 669,2 million refer to equity investments, while about five per cent, or USD 243,6 million was transferred to the level of retained profit (Buletin of the Croatian National Bank, 2006). During 1998, USD 626 million was invested in Croatia, and the highest portion of investments related to investments by foreign companies operating in Croatia. The greatest inflow of foreign investments was realised in 1999, and amounted USD 1,2 billion. It originated from the first round of privatisation of HT shares. The second round of privatisation of HT was not realised in 2000 , for reasons of which the inflow of foreign investments was a bit weaker than expected. In this year, the majority of Croatian banks were transferred into the ownership of foreigners. PBZ and Splitska banka were sold to the Italians, and Riječka banka was sold to Germans. Foreign investments of that time went into several economic activities. About 65 per cent of the total investment amount was invested in three eonomic activities; 24 per cent in telecommunications, 21 per cent in monetary business activities, and 20 per cent in the pharmaceutical indsutry. Except in these activitities, foreign investments were made into the oil and gas industry, which was a result of the co-operation of INA and AGIP in the Adriatic, while the rest was invested in the cement indsutry. According to these data, it is evident that most investments were made in the production and not in the trade industry, as was advocated by the majority of economists. Only about 4-4,5 per cent of total investments were made in the trade industry. All other investments were made in other industries such as production of building material (1,9 per cent), industrial gases (1,4 per cent), production of beer (1,3 per cent), non-alcoholic beverages (1,3 per cent), production of radio, TV and telephone devices (1,2 per cent), sanitary ceramics (1,2 per cent). The biggest foreign investors of the time were the USA with USD 1,11 billion, Germany with USD 1,06 billion, Austria with USD 890,2 billion, and Italy and Holland (Babić, 2001.).

Current experience in business activities with foreign capital indicates its interest in investing in large infrastructure facilities under direct protection of the government, such as roads, financial institutions, insurances, energy potentials, and other large facilities of wider European interest. Table 1 and Chart 1 show foreign investments in the Croatian economy.

Table 1. Foreign Investments in Croatia from 1993-2014 (in mil EUR)

\begin{tabular}{|c|c|c|c|c|c|c|c|c|}
\hline \multirow[b]{2}{*}{ Year } & \multicolumn{3}{|c|}{ Equity Investments } & \multirow[b]{2}{*}{ Retained profit 1) } & \multicolumn{3}{|c|}{ Debt Instruments } & \multirow[b]{2}{*}{ Total } \\
\hline & $\begin{array}{l}\text { In direct } \\
\text { investment } \\
\text { company }\end{array}$ & $\begin{array}{c}\text { In direct investor } \\
\text { (converse } \\
\text { investment) }\end{array}$ & $\begin{array}{c}\text { Between } \\
\text { horizontally } \\
\text { associated } \\
\text { companies }\end{array}$ & & $\begin{array}{c}\text { In direct } \\
\text { investment } \\
\text { company }\end{array}$ & \begin{tabular}{|c|} 
In direct \\
investor \\
(converse \\
investment) \\
\end{tabular} & $\begin{array}{c}\text { Between } \\
\text { horizontally } \\
\text { associated } \\
\text { companies }\end{array}$ & \\
\hline 1993 & 15,2 & 0,0 & 0,0 & $\mathrm{n} / \mathrm{a}$ & $\mathrm{n} / \mathrm{a}$ & $\mathrm{n} / \mathrm{a}$ & $\mathrm{n} / \mathrm{a}$ & 15,2 \\
\hline 1994 & 5,7 & 0,0 & 0,0 & $\mathrm{n} / \mathrm{a}$ & $\mathrm{n} / \mathrm{a}$ & $\mathrm{n} / \mathrm{a}$ & $\mathrm{n} / \mathrm{a}$ & 5,7 \\
\hline 1995 & 5,4 & 0,0 & 0,0 & $\mathrm{n} / \mathrm{a}$ & $\mathrm{n} / \mathrm{a}$ & $\mathrm{n} / \mathrm{a}$ & $\mathrm{n} / \mathrm{a}$ & 5,4 \\
\hline 1996 & 20,7 & 0,0 & 0,0 & $\mathrm{n} / \mathrm{a}$ & $\mathrm{n} / \mathrm{a}$ & $\mathrm{n} / \mathrm{a}$ & $\mathrm{n} / \mathrm{a}$ & 20,7 \\
\hline 1997 & 161,7 & 0,0 & 0,0 & 6,7 & 53,0 & 0,0 & 0,0 & 221,4 \\
\hline 1998 & 69,9 & 0,0 & 0,0 & 2,2 & 72,9 & 0,0 & 0,0 & 145,1 \\
\hline 1999 & 59,7 & 0,0 & 0,0 & 2,1 & $-1,5$ & 0,0 & 0,0 & 60,4 \\
\hline 2000 & 37,6 & 0,0 & 0,0 & 8,5 & 5,5 & $-0,7$ & 0,0 & 50,8 \\
\hline 2001 & 123,8 & 0,0 & 0,0 & 19,8 & $-9,9$ & $-0,2$ & 0,0 & 133,6 \\
\hline 2002 & 592,7 & 0,0 & 0,0 & 8,3 & 7,7 & 0,3 & 0,0 & 609,0 \\
\hline 2003 & 70,2 & 0,0 & 0,0 & 31,7 & 15,3 & 1,5 & 0,0 & 118,8 \\
\hline 2004 & 94,1 & 0,2 & 0,0 & 165,8 & 23,6 & 17,8 & 0,0 & 301,6 \\
\hline 2005 & 57,4 & 0,0 & 0,0 & 63,8 & 59,8 & 0,0 & 0,0 & 181,1 \\
\hline 2006 & 143,6 & 0,0 & 0,0 & 63,5 & 12,5 & $-16,4$ & 0,0 & 203,1 \\
\hline 2007 & 144,9 & 0,0 & 0,0 & 123,3 & $-20,4$ & 4,2 & 0,0 & 252,0 \\
\hline 2008 & 943,8 & 0,0 & 0,0 & 118,6 & $-106,8$ & 24,5 & 0,0 & 980,1 \\
\hline 2009 & $1.030,2$ & 0,0 & 0,0 & $-117,1$ & 35,2 & 22,1 & 0,0 & 970,3 \\
\hline 2010 & $-264,3$ & 0,0 & 0,0 & 7,3 & 369,2 & 13,1 & 0,0 & 125,3 \\
\hline 2011 & 182,4 & 0,0 & 0,0 & $-7,4$ & $-323,9$ & $-19,9$ & 0,0 & $-168,8$ \\
\hline 2012 & 148,4 & 0,0 & 0,0 & $-70,8$ & $-134,1$ & $-6,5$ & 0,0 & $-63,0$ \\
\hline 2013 & 96,6 & 0,0 & 0,0 & $-163,5$ & $-81,4$ & 30,5 & 0,0 & $-117,7$ \\
\hline 1.,2.i 3.tr. 2014 & $1.590,8$ & 0,0 & 0,0 & 25,3 & 33,3 & 223,9 & 7,1 & $1.880,5$ \\
\hline TOTAL & $5.330,6$ & 0,3 & 0,0 & 288,2 & 9,8 & 294,4 & 7,1 & $5.930,4$ \\
\hline
\end{tabular}

Source: Croatial National Bank, available at: www.hnb.hr accessed in January of 2015 
Chart 1. Direct Foreign Investments in Millions of KN $2004-2012$

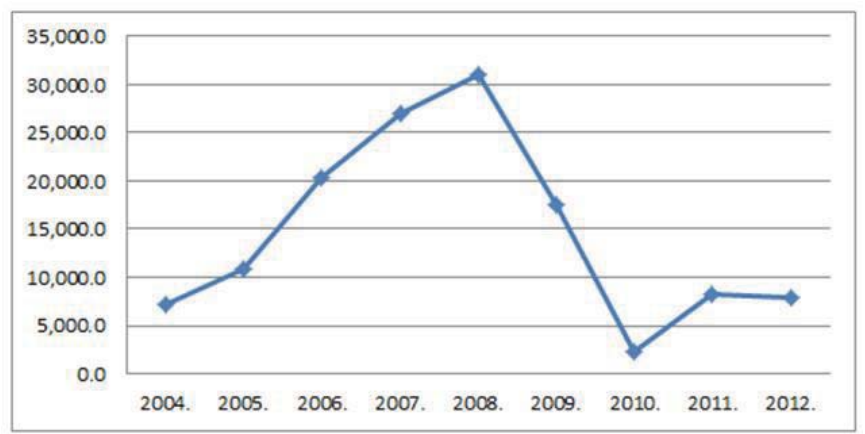

Source: Croatian National Bank, available at: www.hnb.hr , accessed in January of 2015

Foreign capital is oriented towards parts of the economy that represent a specific Croatian advantage. Besides, private foreign capital is interested in parts of the economy in which medium complex technology is applied. Analysis of investments according to investors' countries shows that, traditionally, the biggest investors in the Croatian economy come from Austria and Germany, while the most recent investments were made by France, which invested over a billion euros in Croatia. Table 2 shows foreign direct investments in Croatia according to activities, and Table 3 foreign direct investments in the industry.

Table 2. Foreign Direct Investments in Croatia According to Activities, in Millions KN

\begin{tabular}{|c|l|c|}
\hline NCA 2002 & Activityt & Total investments 2004 - 2012 \\
\hline & Total foreign direct investments & $132.647,3$ \\
\hline 65 & Financial mediation, except insurance and pension funds & $45.648,3$ \\
\hline 51 & Wholesale and mediation in trade & $17.151,4$ \\
\hline 70 & Real-estate business & $10.810,3$ \\
\hline 74 & Other businesses & $9.420,1$ \\
\hline 23 & Production of coke, refined petroleum products and nuclear fuel & $9.119,1$ \\
\hline 52 & Retail, repairs of household utilities & $7.362,2$ \\
\hline & Equity investment in real estate & $5.317,6$ \\
\hline 11 & Oil and gas drilling, service industries & $3.408,6$ \\
\hline 26 & Production of other non-metal mineral products & $3.109,8$ \\
\hline 55 & Hotels and restaurants & $2.844,8$ \\
\hline 66 & Insurance and pension funds, except obligatory insurance & $2.347,2$ \\
\hline 92 & Recreational, cultural and sports activities & $1.989,4$ \\
\hline & Other activities & $1.626,0$ \\
\hline 15 & Production of food and beverages & $1.194,9$ \\
\hline 41 & Collection, purification and distribution of water & $1.119,8$ \\
\hline 50 & Trade of motor vehicles, repair of motor vehicles & $1.063,4$ \\
\hline
\end{tabular}

Source: Croatian National Bank. Available at: www.hnb.hr, accessed in January of 2015

Table 3. Foreign Direct Investments in the Croatian Industry (mil EUR)

\begin{tabular}{|l|c|c|c|c|c|c|}
\hline & 2009 & 2010 & 2011 & 2012 & 2013 & 1. tr.2014 \\
\hline Production of coke, refined petroleum products and nuclear fuel & 110.6 & -0.7 & 68.7 & 12.9 & -119.6 & 15.9 \\
\hline Production of chemicals and chemical products & -18.7 & -440.7 & 244.1 & -46.1 & 30.2 & 29.3 \\
\hline Production of other non-material mineral products & 11.5 & -56.7 & 56.5 & -6.7 & -30.7 & 4.8 \\
\hline Production of food and beverages & -175.5 & -4.5 & -6.7 & -24.4 & 79.6 & 6.6 \\
\hline Production of electrical devices and appliances & 8.3 & 11.1 & -4.3 & -5.8 & 12.7 & 2.3 \\
\hline Production of textile & 18.3 & 9.4 & 32.7 & 1.7 & 7.1 & 0.8 \\
\hline Production of rubber and plastic products & 2.1 & 3.5 & 1.2 & 4.2 & 3.0 & -0.1 \\
\hline
\end{tabular}




\begin{tabular}{|l|c|c|c|c|c|c|}
\hline Production of machines and devices & 35.8 & 6.2 & -4.3 & -6.0 & 4.1 & 10.1 \\
\hline Leather processing, making of accesories and shoes & 16.1 & 14.7 & 12.0 & 13.2 & -6.6 & -2.1 \\
\hline Production of clothes, finishing and colouring of fur & -5.8 & 4.9 & 6.5 & 9.6 & 3.2 & 0.6 \\
\hline Oil and gas drilling & -10.4 & -70.7 & -49.1 & -52.6 & -12.6 & -2.9 \\
\hline Supply of electrical energy, gas, steam and hot water & -5.6 & 10.8 & 10.6 & 6.4 & 13.3 & 1.7 \\
\hline
\end{tabular}

\section{Source: CNB}

Analysis of investments according to investors' countries shows that, traditionally, the biggest investors in the Croatian economy come from Austria and Germany, while the most recent investments were made by France, which invested over a billion euros in Croatia. Table 4 shows foreign direct investments in Croatia according to countries of origin.

Table 4. Foreign Direct Investments in Croatia According to Countries of Origin

\begin{tabular}{|c|c|c|c|c|c|c|}
\hline Country & 2009 & 2010 & 2011 & 2012 & 2013 & 1. tr.2014 \\
\hline Austria & 441,9 & $-115,5$ & 211,8 & 283,6 & 31,1 & 78,9 \\
\hline Holland & 694,7 & $-264,4$ & 253,9 & $-231,4$ & 226,2 & 964,1 \\
\hline Germany & 186,8 & 92,3 & 225,3 & $-109,8$ & 140,6 & $-906,3$ \\
\hline Hungary & 164,5 & $-10,3$ & 104,2 & 41,7 & $-172,0$ & 23,1 \\
\hline Luxembourg & 143,9 & 111,5 & 1332,9 & 176,3 & 45,5 & 30,5 \\
\hline Italy & 87,2 & 142,3 & 22,9 & 39,5 & 91,2 & 22,4 \\
\hline France & 42,0 & 17,1 & 5,5 & 2,7 & 17,2 & $-45,6$ \\
\hline Slovenia & 112,4 & 89,1 & 16,6 & $-6,2$ & $-24,0$ & $-8,9$ \\
\hline Sweden & 337,3 & 8,4 & 4,7 & $-22,8$ & $-44,6$ & 13,2 \\
\hline Switzerland & 6,4 & 0,8 & 24,8 & 7,4 & 4,4 & 0,2 \\
\hline Great Britain & 40,2 & $-48,7$ & 20,5 & 6,9 & 40,7 & 21,4 \\
\hline The Czech Republic & $-21,5$ & 13,6 & 5,8 & 308,8 & $-8,2$ & 3,4 \\
\hline Russia & 6,6 & 12,0 & 29,2 & 25,9 & 41,5 & 1,6 \\
\hline Ireland & 41,5 & 82,3 & 6,8 & 1,3 & 0,7 & 1,9 \\
\hline Denmark & 21,7 & $-10,6$ & $-20,0$ & 5,7 & 23,7 & $-1,6$ \\
\hline Slovakia & 6,1 & 7,6 & 11,5 & 10,2 & 32,6 & 0,3 \\
\hline USA & 26,0 & $-17,9$ & $-56,8$ & $-70,0$ & 14,3 & 5,0 \\
\hline
\end{tabular}

\section{Source: CNB}

In order to make investments in certain parts of the economic system, Croatia needs loan investment capital; however, judging from the experiences of other countries that surpassed the development level at which Croatia is now, loan capital should be used very carefully, because in such forms of investment, all the risk is transferred to domestic companies that are usually unable to manage this type of investment. This capital should be returned by certain deadlines with interest, and the selection of investment location and effectiveness of the use becomes an exclusive obligation of domestic companies. On the other hand, by using investment profit-gaining foreign capital, all or partial investment risk is shared by the foreign investor and domestic entrepreneur. This co-operation between a domestic entrepreneur and foreign investor is achieved through the assistance of the foreign investor in the transferring of new technology into the country and opening of new, preferably foreign markets, which could have a positive impact on the change in the ownership structure in the company, but also improvement of the qualification structure of the employees, faster development of entrepreneurial and managerial staff, etc. It must be taken into account that the every capital is directed to fast generation of profit to its owner.

All things considered, according to CNB analyses, 2008 was a record year in terms of investments in Croatia. Investments in 2006 were large-scale, because at that time, Pliva was sold. This upward trend of foreign investments in Croatia was contributed by the takeover of several large companies. The biggest investment of this kind was realised by the French Societe Generale that bought Splitska banka, and another large investor was the American Barr that bought Pliva. Foreign investors are mostly attracted to the financial part of the Croatian economy, and this economic part attracted about EUR 790 million of investments in nine months in 2006. Along with the financial part of the economy, foreign investments were made in several companies dealing with production of food and beverages, where the level of investment amounted about EUR 190 million. This was followed by telecommunications with investments of about EUR 
127 million. Investments in oil amounted EUR 94 million, and in all other parts of the economy, foreign capital was represented at the level of about EUR 50 million (Buletin of the Croatian National Bank, 2006). Since the beginning of the crisis, i.e. from 2009, the number of foreign investments significantly declined. In the past year, the investments amounted KN 52 billion, i.e. they fell from KN 89,6 billion to 37,4 billion. High level of foreign investments in Croatia is primarily supported by the profit gained by foreign companies that operate successfully in Croatia, but they have also become desirable employers, because they provide higher salaries and are more productive and innovative in their activities. Table 5 shows the parameters of domestic and foreign companies.

Table 5. Domestic and Foreign Companies According to Parametres

\begin{tabular}{|l|c|c|}
\hline Foreign vs domestic & Companies in foreign ownership & Companies in domestic ownership \\
\hline Number of companies & 733 & 10,826 \\
\hline Number of employees & 39,746 & 191,021 \\
\hline Average net salary & $5477 \mathrm{kn}$ & $4411 \mathrm{kn}$ \\
\hline Source per employee & $471,650 \mathrm{kn}$ & $201,159 \mathrm{kn}$ \\
\hline Share of export in total operating revenues & 56 & 30 \\
\hline Export/import ratio & $164 \%$ & $191 \%$ \\
\hline Labour productivity & 183,505 & 151,429 \\
\hline Return on capital & $9,1 \%$ & $15,8 \%$ \\
\hline Indebtedness & $51 \%$ & $58 \%$ \\
\hline Short-term debt & $70 \%$ & $94 \%$ \\
\hline Innovation & $40 \%$ & $29 \%$ \\
\hline Development of new products at the foreign market & $15,8 \%$ & $8,2 \%$ \\
\hline
\end{tabular}

Source: Jutarnji list 29.03.2014

It is interesting that foreign companies that realise profit in Croatia increasingly reinvest their profit in other parts of the economic system. Increasing number of Croatian companies is bought by foreign investors. This type of reinvestment is especially popular with foreign investors in the banking sector. They were forced to this procedure by the CNB that introduced financial restrictions that significantly raise the costs of borrowing abroad, and increasingly use their achieved profit to undertake further credit activities.

\section{Conclusion}

The need for rapid development of Croatian economic system has created the need for various types of foreign investments. Such investments should be in accordance with the needs and demands of the domestic market as well as open domestic co-operation with the international market. Croatian economic development should be based on scientific approach and research that would show all the good or bad sides of such ventures, taking into account the overall economic strategy of the Republic of Croatia. Special attention should be devoted to future development of national economic operators, their operational and financial bonding and integration into new organisational forms modelled on comparable groups in the world. In these activities, the government should have an important role; it should use efficient legislation to have an impact on the rule of law, ensure free operation of economic market principles, and prevent each attempt of market closure or creating a monopoly that would affect proper functioning of the market. The government should provide active development policy which would open space for developmental initiatives and creativity. In order to meet the existing needs and demands, big investment capital is necessary that should be collected from domestic or foreign sources. Presently, but also in the distant future, Croatia will not be able to collect the sufficient amount of capital to achieve these goals. Croatia has many unused resources. Smart activation of these resources could attract domestic and foreign capital. This capital can originate from a variety of sources and can be in different forms. The investment of foreign capital into a country does not only depend on the capital itself, but also on the conditions in this particular country. Previous experiences from other countries suggest that high expectations from the expected capital investments from abroad often have no real basis. One should not passively wait for developments, but rather try to use a real situation to achieve the maximum. When using foreign capital, particular attention should be devoted to the capital of Croatian emigrants i.e. people working abroad. It should be noted that capital, in terms of free market, knows no national bonds and aims to get away from the native country by creating better conditions in another country if the native country 
has no prospect of making profit.

\section{References}

Ačimović, A. (1987) Međuzavisnost trgovine i turizma, "Susreti na dragom kamenu 87", Pula.

Babić, A. (2001) Teorija stvarnih inozemnih izravnih ulaganja u svijetu i u tranzicijskim zemljama s posebnim osvrtom na Hrvatsku, Pregledi, Croatian National Bank, Zagreb.

Buletin of the Croatian National Bank, 2006

Croatian National Bank, available at: www.hnb.hr

Jutarnji list

Novi list

Ostojić, D. (1995) Kakve pogodnosti stranom kapitalu, Gospodarstvo, No. 69.

Pulić, A., Sundać, D. (2001) Intelektualni kapital: ključni resurs 21. stoljeća, the second amended edition, International Business Consulting Center, Rijeka

Vizjak, A. (1995) The Continental and Coastal Tourism of Croatia, Tourism and Hospitality Management, WIFI Österreich, Wien / Opatija No. 1.

Zelenika, R. (2007) Znanje - temelj društva blagostanja "obrazovna i znanstvena industrija", University of Rijeka, Faculty of Economics Rijeka. 